\title{
Formation of the Concept of the State's Transition to Activity in the Conditions of a New Technological Order
}

\section{Valery Vladimirovich Glushchenko}

\author{
Doctor of Technical Sciences, Associate Professor, \\ Moscow Polytechnic University, \\ Professor of the Project Activity Center, \\ Moscow, Russia \\ *Corresponding author details: Dr. Valery Vladimirovich Glushchenko; \\ glu-valery@yandex.ru
}

\begin{abstract}
The subject of the article is the development of a concept for the transition of organizations to the eighth technological mode; the object of the article is the eighth technological mode; the purpose of the work is to increase the efficiency of the processes of transition of organizations to the eighth technological mode; to achieve this goal, the following tasks are solved: the geopolitical and socio-economic roles and results of the transition of organizations to the eighth technological mode are described; a system analysis of technological modes is carried out (tables of elements and properties of technological modes are developed); - development and description of practical tasks of the policy of transition of organizations to the eighth technological order; the structure of the policy and the content of the elements of the policy of transition to the eighth technological order are described; the criteria for evaluating the effectiveness of the policy of transition of organizations to the eighth technological order are given; the scientific methods of this article are system, historical, logical and comparative analysis, heuristic synthesis, political science, system approach, heuristic forecasting, expert methods, efficiency theory; the scientific novelty of the work is determined by the synthesis of the policy of transition of organizations to the eighth technological order, the formation of a set of criteria for assessing the geopolitical and socio-economic effectiveness of the policy of organizations for the transition to the eighth technological order.
\end{abstract}

Keywords: technological structure; politics; synthesis; system; analysis; philosophy; ideology; planning; strategy; tactics; organization; economy; efficiency; system approach; representation; criterion; properties; elements

\section{INTRODUCTION}

The relevance of this work is determined by the need to improve the effectiveness of the transition policy of organizations (state, corporation, cluster, technology platform, etc.) to work in the conditions of the eighth technological order in the global economy. At the same time, it is recommended to take into account the process of overcoming the global financial and systemic crisis associated with the formation of a new technological order.

The transition to the eighth technological order can be called a key problem of the global economy and specific organizations.

The subjects of the process of transition to the eighth technological order can be named: global governance bodies (the World Bank and others); national governments; political parties; managers of corporations and firms, and others.

The hypothesis of the article is the statement that the development of a policy of transition to the eighth technological order will be able to increase the efficiency of the processes of formation of the eighth technological order in the global and national economies.
The purpose of the work is to increase the efficiency of the processes of transition of organizations to the eighth technological order.

To achieve this goal, the following tasks are solved:

- the geopolitical and socio-economic roles and results of the transition of organizations to the eighth technological order are described;

- a system analysis of technological orders is carried out (tables of elements and properties of technological structures are being developed);

- development and description of practical tasks of the policy of transition of organizations to the eighth technological order;

- the structure of the policy and the content of the elements of the policy of transition to the eighth technological order are described;

- the criteria for evaluating the effectiveness of the policy of transition of organizations to the eighth technological order are given. 
The object of the article is organizations (states, corporations, clusters, technology platforms, etc.) in the conditions of the eighth technological order.

The subject of the article is the development of a policy for the transition of organizations to the eighth technological order.

The study of literary sources on the topic of this article showed the following. The conceptual approach is used in the development of modernization projects in the economy [1, $\mathrm{p}$. $40-43$; 2, p. 53-55; 3, p. 37-43]. Regional policy is actively developing in France [4, p. 353-358]. The coordination of interests is considered as part of the policy [5, pp. 272-278] Innovation policy is developed to justify the strategy of firms and corporations [6, p. 2]. The increasing role of politics leads to the fact that the science of politics needs its further development [7, p. 2]. There are known attempts to describe the process of technological development as a sequence of technological orders [8; 9, p. 3-29].

They perform forecasts of the structure of a new technological order [10, p. 182-189]. Researchers form methods of strategic planning for the development of a new technological order [11, p. 82-89; 12, p. 30-38].

The methodological basis for strategic planning is the development of the theory of technological orders $[13, p$ $65-82 ; 14$, p. 2].

To study technological orders, system analysis is used [15, p. 22-34]. This allows us to say that the technological order is a large system. For the study of large systems, the theory of hierarchical systems was proposed [16, p. 12]. The development of a new technological order affects the technological power of the state. At the same time, Zbigniew Brzezinski believed: "The economic dynamism of America serves as a necessary precondition for ensuring a dominant role in the world" [17, p.34]. The development of a new technological order can affect the geopolitical status and geopolitical risk of the state. The influence of geopolitical risk on the economic efficiency of innovation activity in the country is studied [18, p. 46; 19, p. 200].

Method. The concept of the transition of an organization (state, region, corporations, clusters, technological platforms, etc.) to the eighth technological order can be interpreted as a systematic view of the process and results of the formation of this technological order in society and the economy. Such a concept systematically combines such elements of it: ideology; culture; politics; strategy and tactics of such a transition to a new technological order.

The ideology of the transition of organizations to the eighth technological order can be defined: firstly, as the main idea of the formation of this order, way of life (improving the safety and comfort of people's lives); secondly, the way of distributing power in this process.

The policy of transition of organizations (state, region, corporations, clusters, technology platforms, etc.) to the eighth technological order in this article will be understood as a set of measures. Such a policy is a set of measures aimed at: modernization of the production capacities of organizations; modernization of the products of these organizations; development of new types of technologies (nanotechnologies, neurotechnologies, digitalization technologies, information technologies, resource-saving technologies, environmentally friendly technologies); the introduction of these technologies into the products of previous technological orders; the formation of social production institutions $[20$, pp. 554563] and others.
The activities included in such a policy should be coordinated with each other.

Let us assume that the policy of transition of the economy and society to the eighth technological order includes strategy and tactics. The strategy is responsible for the long-term perspective of this process of transition from one technological order (mode) to another [12, p.30-38]. Tactics ensures the current implementation of strategic plans, taking into account the requirements of: ensuring solvency; sustainable development of this process of transition to a new technological order.

We agree to proceed from the fact that the" technological order " is a complex hierarchical (multi-level) system. Therefore, the main research methods should be: the theory of hierarchical systems [16, p. 2]; system approach; system analysis; search heuristic forecasting and others in such studies, we will take into account that the authors of the theory of large systems note: 1 . " First of all, the very concept of system complexity depends on the point of view. What seems to a psychologist to be a complex or large system may turn out to be just an elementary link in the eyes of an economist" [16, p. 17]; 2. "We can even say that the importance and wide prevalence of multi-level systems are not yet well understood" [16, p. 17].

This opinion of the authors of the theory of large systems is confirmed by the practice of research by economists. Economists consider it necessary to interpret the technological order as an economic system [9, p. 3-29]. With this approach, we know the proposal to understand the system of key global institutions by the technological order. In this case, it is believed that the subject of the functioning of the technological order is the process of expanded reproduction of capital [9, p. 3-29].

The concept of transition to a new technological order is based on the methodology of the system approach. The systematic approach consists in studying and considering all the elements (parts) and/or properties of the object of research (technological order) in their mutual connection. The system analysis of the eighth technological order can be called the establishment of structural connections and the study of the properties of both this entire technological order and its individual elements.

The system analysis performed in this work shows the existence of a system connection between the factors of the world order and the factors of the technological order [21, p. 34]. It can be argued that there is a systemic influence of production technologies on: types of money (gold, credit money; mottos; cryptocurrencies [22, p. 7-16]); management methods; the world currency system; on forms of doing business and types of business processes in the economy, in the corresponding historical and, at the same time, technological periods.

Therefore, we will call the" technological order" a systematic combination of: the technological basis of production and the life of society; socio-industrial institutions; types of business processes; methods and tools of management; concepts of personnel management of organizations in the economy and society at a certain stage of the historical, technological, economic, social, cultural process of economic and social development.

The basics of the scientific theory of technological orders are described in $[13$, pp. $65-82 ; 14$, p. 2]. The further formation of the scientific theory of technological orders should be an effective methodological tool for forming the concept of transition to a new technological order. 
An example of a system analysis of the historical process of technological development is given in Tables No. $1,2$.
In Table No. 1, a system analysis of the structure and elements of technological orders is carried out.

TABLE 1: System analysis of the structure and elements of technological structures (beginning)

\begin{tabular}{|c|c|c|c|}
\hline $\begin{array}{l}\text { № } \\
\text { П/ா }\end{array}$ & $\begin{array}{c}\text { Properties of technological orders } \\
\text { (structures) } \\
\text { /number, names } \\
\text { technological orders, time period }\end{array}$ & New types of products & $\begin{array}{l}\text { Types of production } \\
\text { enterprises }\end{array}$ \\
\hline$(1)$ & $(2)$ & (3) & $(4)$ \\
\hline 1 & $\begin{array}{l}\text { "1st" technological order; } \\
\text { horse traction; } \\
\text { Time period 2000 BC - 9th century AD, }\end{array}$ & $\begin{array}{l}\text { Natural raw materials, } \\
\text { agricultural products, } \\
\text { transport services } \\
\end{array}$ & Family, community \\
\hline 2 & $\begin{array}{l}\text { "2nd" technological order; } \\
\text { Windmill, a water mill; } \\
\text { Time period 9th century-1770, }\end{array}$ & $\begin{array}{l}\text { Flour, sunflower oil; products of } \\
\text { mechanical processing of } \\
\text { agricultural products }\end{array}$ & Family, clan, craftsman, miller \\
\hline 3 & $\begin{array}{l}\text { "3rd" technological order; } \\
\text { Textile machines; } \\
\text { Time period 1770-1830, }\end{array}$ & $\begin{array}{l}\text { Machine-made fabrics, } \\
\text { manufactory products }\end{array}$ & $\begin{array}{l}\text { Textile manufactories, } \\
\text { Enterprises; }\end{array}$ \\
\hline 4 & $\begin{array}{l}\text { "4th" technological order; } \\
\text { steam engine; } \\
\text { Time period } 1830-1880 \text {, }\end{array}$ & $\begin{array}{l}\text { Steam engines; mechanisms; } \\
\text { locomotives, rails; sleepers; }\end{array}$ & International monopolies \\
\hline 5 & $\begin{array}{c}\text { "5th" technological order; electric } \\
\text { motor and internal combustion engine; } \\
\text { Time period } 1880-1930,\end{array}$ & $\begin{array}{l}\text { Cars, diesel locomotives, } \\
\text { airplanes, washing machines, } \\
\text { refrigerators; radio, telegraph }\end{array}$ & Multinational corporations, \\
\hline 6 & $\begin{array}{c}\text { "6th" technological order; electronic } \\
\text { computers; } \\
\text { Time period 1930-1970, }\end{array}$ & $\begin{array}{c}\text { Electronic computers, } \\
\text { televisions; automation tools; } \\
\text { flexible automated production } \\
\text { complexes }\end{array}$ & Multinational corporations, \\
\hline 7 & $\begin{array}{c}\text { The " 7th " technological order; } \\
\text { microelectronics and microprocessors; } \\
\text { Time period 1970-2010; }\end{array}$ & $\begin{array}{l}\text { personal computers; ATMs; } \\
\text { plastic bank cards; mobile } \\
\text { phones; }\end{array}$ & $\begin{array}{c}\text { Multinational corporations, } \\
\text { virtual corporations; } \\
\text { strategic alliances of corporations } \\
\end{array}$ \\
\hline 8 & $\begin{array}{l}\text { The " 8th " technological order; } \\
\text { nanotechnologies and } \\
\text { neurotechnologies; } \\
\text { Time period 2010-2040, }\end{array}$ & $\begin{array}{l}\text { 3-D printing products, } \\
\text { information products, } \\
\text { transformation of human } \\
\text { thinking (clip thinking) }\end{array}$ & $\begin{array}{l}\text { global information systems; } \\
\text { clusters; technology platforms }\end{array}$ \\
\hline
\end{tabular}

Source: Developed by the author

TABLE 1: System analysis of the structure and elements of technological structures (end)

\begin{tabular}{|c|c|c|c|}
\hline $\begin{array}{l}\text { № } \\
\text { П/ா }\end{array}$ & $\begin{array}{c}\text { Properties of technological } \\
\text { orders (structures) } \\
\text { /number, names } \\
\text { technological orders, time } \\
\text { period }\end{array}$ & $\begin{array}{l}\text { Type of money; } \\
\text { international monetary system }\end{array}$ & $\begin{array}{l}\text { World order, socio-economic } \\
\text { formation }\end{array}$ \\
\hline (1) & (2) & (5) & (6) \\
\hline 1 & $\begin{array}{l}\text { "1st" technological order; } \\
\text { horse traction; } \\
\text { time period } 2000 \mathrm{BC}- \\
\text { 9th century AD, }\end{array}$ & $\begin{array}{l}\text { Individual goods (grain, cattle, furs) } \\
\text { are equivalent; money changers } \\
\text { and usurers }\end{array}$ & $\begin{array}{l}\text { communal and tribal system; } \\
\text { slavery; feudalism; communities; } \\
\text { principalities; kingdoms }\end{array}$ \\
\hline 2 & $\begin{array}{l}\text { "2nd" technological order; } \\
\text { Windmill, a water mill; } \\
\text { Time period 9th century-1770, }\end{array}$ & $\begin{array}{l}\text { Gold as a universal equivalent; } \\
\text { money changers and usurers; } \\
\text { receipts and bills of exchange; } \\
\text { monasteries as repositories of gold }\end{array}$ & $\begin{array}{l}\text { feudalism; principalities; } \\
\text { kingdoms; land empires }\end{array}$ \\
\hline 3 & $\begin{array}{l}\text { "3rd" technological order; } \\
\text { Textile machines; } \\
\text { Time period 1770-1830, }\end{array}$ & $\begin{array}{c}\text { National gold currencies; paper } \\
\text { money; central and commercial } \\
\text { banks; stock exchanges; securities }\end{array}$ & $\begin{array}{l}\text { monarchies; maritime empires; } \\
\text { capitalism; }\end{array}$ \\
\hline 4 & $\begin{array}{l}\text { "4th" technological order; } \\
\text { steam engine; } \\
\text { Time period 1830-1880, }\end{array}$ & $\begin{array}{c}\text { Paris international monetary } \\
\text { System, full-fledged (gold) money; } \\
\text { paper money }\end{array}$ & $\begin{array}{l}\text { land and sea empires; } \\
\text { monarchies; capitalism; }\end{array}$ \\
\hline 5 & $\begin{array}{c}\text { "5th" technological order; electric } \\
\text { motor and internal combustion } \\
\text { engine; } \\
\text { Time period 1880-1930, }\end{array}$ & $\begin{array}{l}\text { Genoese gold-motto system; three } \\
\text { international currency blocks; } \\
\text { credit money }\end{array}$ & $\begin{array}{l}\text { Capitalism; imperialism; nation- } \\
\text { states; republics }\end{array}$ \\
\hline 6 & $\begin{array}{l}\text { "6th" technological order; } \\
\text { electronic computers; } \\
\text { Time period 1930-1970, }\end{array}$ & $\begin{array}{l}\text { gold and mottos, the international } \\
\text { Breton-Wood currency system, } \\
\text { credit money; }\end{array}$ & $\begin{array}{c}\text { States, military-political blocs of } \\
\text { States, a bipolar world; the United } \\
\text { Nations (UN) }\end{array}$ \\
\hline
\end{tabular}




\begin{tabular}{|c|c|c|c|}
\hline $\begin{array}{l}\text { № } \\
\text { П/ா }\end{array}$ & $\begin{array}{l}\text { Properties of technological } \\
\text { orders (structures) } \\
\text { /number, names } \\
\text { technological orders, time } \\
\text { period }\end{array}$ & $\begin{array}{l}\text { Type of money; } \\
\text { international monetary system }\end{array}$ & $\begin{array}{l}\text { World order, socio-economic } \\
\text { formation }\end{array}$ \\
\hline 7 & $\begin{array}{l}\text { The " 7th " technological order; } \\
\text { microelectronics and } \\
\text { microprocessors; } \\
\text { Time period 1970-2010; }\end{array}$ & $\begin{array}{c}\text { demonetization of gold; the } \\
\text { Jamaican International Monetary } \\
\text { System; electronic and digital } \\
\text { money; Special Drawing Rights } \\
\text { (SDR, SDRs); Society for Worldwide } \\
\text { Interbank Financial } \\
\text { Telecommunications (SWIFT); } \\
\text { торговые системы }\end{array}$ & $\begin{array}{l}\text { Globalization; States; trade and } \\
\text { economic blocks of states; } \\
\text { military and political blocks of } \\
\text { states; } \\
\text { Global unipolar world, Post- } \\
\text { industrial society }\end{array}$ \\
\hline 8 & $\begin{array}{l}\text { The " 8th " technological order; } \\
\text { nanotechnologies and } \\
\text { neurotechnologies; } \\
\text { Time period 2010-2040, }\end{array}$ & $\begin{array}{l}\text { Cryptocurrencies (virtual, } \\
\text { technological money); international } \\
\text { cryptocurrency system; global } \\
\text { trading systems }\end{array}$ & $\begin{array}{l}\text { States; trade and economic blocks } \\
\quad \text { of states; } \\
\text { The process of decentralization of } \\
\text { the global unipolar world; Post- } \\
\text { industrial society; }\end{array}$ \\
\hline
\end{tabular}

Source: Developed by the author

The above system analysis of the entire historical process of the development of modern civilization allows: to form descriptive models of all the technological modes that took place; to form a descriptive model of the eighth technological mode by combining descriptions of elements of this mode; to identify the model of the eighth technological mode as an image of the future for the current period of development.

In turn, this image of the future becomes the basis for the formation of the concept of the development of the eighth technological order. At the same time, the very concept of such development acts as a philosophical and ideological basis for developing a policy for the transition of organizations to the eighth technological order.

The role of the concept of development of the eighth technological order is related to the following. The formation of the correct concept of the development of the eighth technological order will allow the organization to get the maximum effect in the process of technological development.

Let us explain the significance of the effective development of the eighth technological order on the example of such an organization as the state. The formation of the eighth technological order means the transition of the technological basis of advanced organizations to this eighth technological level. The products of enterprises of the eighth technological order will have a higher (eighth) technological level. For this reason, these products will be characterized by a higher monetary innovation multiplier. The innovative money multiplier shows how many times the cost of the final product exceeds the cost of raw materials and raw materials [23, pp. 77-88]. It is known that a modern automobile engine is about 30 times more expensive than the aluminum from which it is made. Timely modernization of this engine through the use of technologies of the eighth technological order will increase its quality. The possibility of such modernization is confirmed in [24]. At the same time, the innovative money multiplier will increase. For example, this multiplier will become equal to 35 . This means that a particular company will receive more profit. This means an increase in revenues to the country's budget. This means an increase in the hardness of the national currency. This means increasing the stability of the national monetary system. At the same time, the increase in the stability of the national monetary system will be the result of the fact that the innovative money multiplier will be significantly larger than the bank money multiplier.
As is known, the bank multiplier characterizes the effect of increasing (multiplying) money on deposit accounts of commercial banks as a result of their movement from one economic entity to another. In this case, the total value of goods is greater than the money supply in the economy. Therefore, in this case: there is no development of inflation; the national currency is solid.

At the same time, the gross domestic product increases; the volume of budget funds increases; the country's development opportunities grow.

If the modernization of the economy is not carried out, then there is a drop in the competitiveness of products. In this case: the gross domestic product is falling; the amount of budget funds is decreasing; the socio-economic crisis is developing; the geopolitical situation of the state is deteriorating.

The importance of forming an effective concept for the development of the eighth technological order is confirmed by such a historical example.

Example \#1. At the beginning of the sixth technological order, there was a mental conflict between the employees of the USSR Academy of Sciences. This conflict is described in [25, pp. 3-14]. In the process of this conflict, genetics and cybernetics were declared false sciences (pseudosciences). Cybernetics and genetics were actually banned. N. I. Vavilov and other supporters of these scientific directions were repressed. The result of this conflict was the lag of the Soviet Union in the field of computer technology. This technological lag, most likely, had disastrous consequences for the country.

Therefore, the formation of an effective concept and policy for the transition of organizations to the eighth technological order is very important for organizations in the 21 st century.

Therefore, the concept of transition to a new technological order should include measures aimed at detecting mental conflicts. Great attention should be paid to the rule of law and respect for human rights [26, c. 303-339].

If we talk about the composition of technological directions in which, as predicted, the development of the eighth technological order will take place, then we can say the following. 
The method of system analysis of the technological structure is described in [15, p. 22-34]. The concept and policy of transition to a new technological order should include measures: firstly, for the development of new technologies; secondly, measures for the development of social institutions [20, pp. 554-563].

It should be remembered that it is the disharmony between the essence of technologies and the content of production institutions that is the source of the crisis [27, pp. 15-35].

Some researchers believe that the eighth technological order will be based on nanotechnologies [28, p. 2]. However, a more advanced system analysis has shown that the technological basis of this technological order will be: neurotechnologies; nanotechnologies; information technologies; resource-saving technologies; digitalization technologies; environmentally friendly technologies $[14$, p.23].
The sources of new scientific achievements will be: a deeper penetration into the structure of the material world (nanotechnology); a more adequate knowledge of the work of the human brain (neutrotechnology); more rational use of raw materials; minimizing damage to nature and more.

At the same time, as already noted, the subject of the new technological way will be to increase the level of comfort and safety of people's lives. The solution of these tasks will also be connected with the problem of resolving contradictions between: technologically developed states and lagging states; between technologically leading social groups and a technologically lagging part of the population, and others. For a more complete reflection of the specifics of the development of individual social groups of the population, a systematic analysis of the properties of the technological structure may be required. In Table No. 2 , a systematic analysis of the properties of technological structures that took place in the history of mankind is carried out.

TABLE 2: System analysis of the properties of technological structures (beginning)

\begin{tabular}{|c|c|c|c|}
\hline $\begin{array}{c}\text { № } \\
\text { п/ா }\end{array}$ & $\begin{array}{l}\text { Properties of technological } \\
\text { orders (structures) } \\
\text { /number, names } \\
\text { technological orders, time period }\end{array}$ & New types of production & $\begin{array}{l}\text { Technologies, methods and } \\
\text { scales of production; structure } \\
\text { and characteristics of labor }\end{array}$ \\
\hline$(1)$ & (2) & (3) & (4) \\
\hline 1 & $\begin{array}{l}\text { "1st" technological order; } \\
\text { horse traction; } \\
\text { time period } 2000 \mathrm{BC}- \\
\text { 9th century AD, }\end{array}$ & $\begin{array}{l}\text { Mechanized processing of } \\
\text { materials based on horse-drawn } \\
\text { traction; transport services based } \\
\text { on horse-drawn traction }\end{array}$ & $\begin{array}{l}\text { Technologies of manual, single and } \\
\text { small-scale production; simple } \\
\text { abstract work }\end{array}$ \\
\hline 2 & $\begin{array}{l}\text { "2nd" technological order; } \\
\text { Windmill, a water mill; } \\
\text { Time period 9th century-1770, }\end{array}$ & $\begin{array}{c}\text { mechanized production of flour, } \\
\text { oils based on the use of vert } \\
\text { energy and water }\end{array}$ & $\begin{array}{l}\text { Technologies of manual, single and } \\
\text { small-scale production; simple } \\
\text { abstract work }\end{array}$ \\
\hline 3 & $\begin{array}{c}\text { "3rd" technological order; } \\
\text { Textile machines; } \\
\text { Time period 1770-1830, }\end{array}$ & $\begin{array}{l}\text { Mechanized textile production of } \\
\text { fabrics }\end{array}$ & $\begin{array}{l}\text { Mechanized technologies of mass } \\
\text { production; professional labor skills }\end{array}$ \\
\hline 4 & $\begin{array}{l}\text { "4th" technological order; } \\
\text { steam engine; } \\
\text { Time period } 1830-1880\end{array}$ & $\begin{array}{c}\text { Mechanized mechanical } \\
\text { processing and transport } \\
\text { services based on a steam engine }\end{array}$ & $\begin{array}{l}\text { Mechanized technologies of mass } \\
\text { production of machine-building } \\
\text { products, knowledge and } \\
\text { professional training of employees }\end{array}$ \\
\hline 5 & $\begin{array}{c}\text { "5th" technological order; electric } \\
\text { motor and internal combustion } \\
\text { engine; } \\
\text { Time period } 1880-1930 \\
\end{array}$ & $\begin{array}{l}\text { Mechanized mechanical } \\
\text { processing; transport services } \\
\text { based on an electric motor and } \\
\text { an internal combustion engine }\end{array}$ & $\begin{array}{c}\text { Technologies of large-scale } \\
\text { conveyor production; special } \\
\text { management and labor } \\
\text { competencies }\end{array}$ \\
\hline 6 & $\begin{array}{l}\text { "6th" technological order; } \\
\text { electronic computers; } \\
\text { Time period 1930-1970, }\end{array}$ & $\begin{array}{l}\text { Production of electronic } \\
\text { computers and automated } \\
\text { production complexes }\end{array}$ & $\begin{array}{l}\text { Technologies of automated large- } \\
\text { scale production; qualification } \\
\text { requirements and job descriptions } \\
\text { for employees }\end{array}$ \\
\hline 7 & $\begin{array}{l}\text { The " 7th " technological order; } \\
\text { microelectronics and } \\
\text { microprocessors; } \\
\text { Time period 1970-2010; }\end{array}$ & $\begin{array}{l}\text { Automated production of trace } \\
\text { elements and printed circuit } \\
\text { boards, microprocessor devices }\end{array}$ & $\begin{array}{l}\text { Flexible automated production; } \\
\text { competence cards and qualification } \\
\text { cards for employees }\end{array}$ \\
\hline 8 & $\begin{array}{l}\text { The " 8th " technological order; } \\
\text { nanotechnologies and } \\
\text { neurotechnologies; } \\
\text { Time period 2010-2040, }\end{array}$ & $\begin{array}{l}\text { Production of materials with } \\
\text { specified properties, } \\
\text { nanotechnology production, } \\
\text { environmentally friendly } \\
\text { production }\end{array}$ & $\begin{array}{c}\text { Nanotechnologies, } \\
\text { neurotechnologies, information } \\
\text { technologies; development of } \\
\text { mentality and social development of } \\
\text { employees }\end{array}$ \\
\hline
\end{tabular}

Source: Developed by the author 
TABLE 2: System analysis of the properties of technological structures (end)

\begin{tabular}{|c|c|c|c|}
\hline $\begin{array}{c}\text { № } \\
\text { П/ா }\end{array}$ & $\begin{array}{c}\text { Properties of technological } \\
\text { orders (structures) } \\
\text { /number, names } \\
\text { technological orders, time } \\
\text { period } \\
\end{array}$ & $\begin{array}{l}\text { Economic policy, Types of } \\
\text { organizational structures in the } \\
\text { economy }\end{array}$ & $\begin{array}{c}\text { Концепция управления } \\
\text { организацией; концепция } \\
\text { работы с персоналом }\end{array}$ \\
\hline (1) & (2) & (5) & (6) \\
\hline 1 & $\begin{array}{l}\text { "1st" technological order; } \\
\text { horse traction; } \\
\text { time period } 2000 \mathrm{BC}- \\
\text { 9th century AD, }\end{array}$ & $\begin{array}{l}\text { Informal economic policy, traditional } \\
\text { organizational structures }\end{array}$ & $\begin{array}{c}\text { Centralization, organization, } \\
\text { control, labor stimulation, } \\
\text { management as an art, unity of } \\
\text { command, human relations }\end{array}$ \\
\hline 2 & $\begin{array}{l}\text { "2nd" technological order; } \\
\text { Windmill, a water mill; } \\
\text { Time period 9th century-1770, }\end{array}$ & $\begin{array}{l}\text { Informal economic policy, traditional } \\
\text { organizational structures }\end{array}$ & $\begin{array}{l}\text { The formation of requirements } \\
\text { for the manager, the theory of } \\
\text { power, the study of the impact } \\
\text { of automation }\end{array}$ \\
\hline 3 & $\begin{array}{l}\text { "3rd" technological order; } \\
\text { Textile machines; } \\
\text { Time period 1770-1830, }\end{array}$ & $\begin{array}{l}\text { Informal economic policy, traditional } \\
\text { organizational structures }\end{array}$ & $\begin{array}{c}\text { Economic theory, financial } \\
\text { theory, the principle of } \\
\text { specialization of industrial } \\
\text { workers }\end{array}$ \\
\hline 4 & $\begin{array}{l}\text { "4th" technological order; } \\
\text { steam engine; } \\
\text { Time period } 1830-1880,\end{array}$ & $\begin{array}{l}\text { Informal economic policy, traditional } \\
\text { organizational structures }\end{array}$ & $\begin{array}{c}\text { Theory of public services, } \\
\text { analysis of employee } \\
\text { motivation }\end{array}$ \\
\hline 5 & $\begin{array}{c}\text { "5th" technological order; electric } \\
\text { motor and internal combustion } \\
\text { engine; } \\
\text { Time period } 1880-1930,\end{array}$ & $\begin{array}{l}\text { Approved economic and industrial } \\
\text { policy, Functional organizational } \\
\text { structures }\end{array}$ & $\begin{array}{l}\text { Scientific management, } \\
\text { methods of statistics in } \\
\text { management, personnel work }\end{array}$ \\
\hline 6 & $\begin{array}{l}\text { "6th" technological order; } \\
\text { electronic computers; } \\
\text { Time period 1930-1970, }\end{array}$ & $\begin{array}{l}\text { Approved economic and industrial } \\
\text { policy; strategic management; } \\
\text { product-oriented organizational } \\
\text { structures of the company }\end{array}$ & $\begin{array}{c}\text { Operational research, system } \\
\text { analysis, marketing, program- } \\
\text { target approach, personnel } \\
\text { management, personnel } \\
\text { motivation systems }\end{array}$ \\
\hline 7 & $\begin{array}{l}\text { The " 7th " technological order; } \\
\text { microelectronics and } \\
\text { microprocessors; } \\
\text { Time period 1970-2010; }\end{array}$ & $\begin{array}{l}\text { Approved innovation policy; matrix } \\
\text { organizational structures; clusters; } \\
\text { technology platforms }\end{array}$ & $\begin{array}{c}\text { Project approach; post- } \\
\text { industrial marketing; } \\
\text { participatory management, } \\
\text { human resource management }\end{array}$ \\
\hline 8 & $\begin{array}{l}\text { The " 8th " technological order; } \\
\text { nanotechnologies and } \\
\text { neurotechnologies; } \\
\text { Time period 2010-2040, }\end{array}$ & $\begin{array}{l}\text { Approved innovation policy; clusters, } \\
\text { technology platforms; Organizational } \\
\text { architecture; organizational design } \\
\text { and culture }\end{array}$ & $\begin{array}{l}\text { Theory of technological orders; } \\
\text { neuromanagement, } \\
\text { neuromarketing; management } \\
\text { of social development of } \\
\text { personnel; higher project } \\
\text { education }\end{array}$ \\
\hline
\end{tabular}

Source: Developed by the author

The following areas of work can be included in the structure of the concept of the organization's transition to a new technological order:

- formation of recommendations for the further development of theoretical provisions of the scientific theory of technological orders;

- activities for the development of applied problems of the theory of technological orders in the branches of the national economy;

- a set of measures to improve the effectiveness of social development programs of the population;

- a set of measures for the development of specific technological platforms and clusters that are engaged in the development of new technologies of this orders (neurotechnologies; nanotechnologies; information technologies; resource-saving technologies; digitalization technologies; environmentally friendly technologies);

- a system of measures aimed at the development of social and industrial institutions of a new technological order;
- creation of an integrated management system for the development of a new technological order;

- measures to develop a set of indicators to assess the effectiveness of the processes of development and functioning of the new technological order, and more. At the same time, all these areas of this concept should be coordinated with each other.

When forming the concept of the state's work in the conditions of a new technological way, it is important to have an idea of the future appearance of this technological way. Such an image of the future can be descriptive in nature.

This image of the future can take the form of a table. In this table, you can combine the characteristics of all the elements and properties of the eighth technological order. The image of the future eighth technological order can have the form of a table. Table 3 shows the image of the future of the eighth technological order. 
TABLE 3: The image of the future of the unique technological order

\begin{tabular}{|c|c|c|}
\hline $\begin{array}{c}\text { № } \\
\text { П/ா }\end{array}$ & $\begin{array}{c}\text { Title characteristics of the image of } \\
\text { the future of the eighth } \\
\text { technological order }\end{array}$ & $\begin{array}{l}\text { Description of the specific characteristics of the image of } \\
\text { the future of the eighth technological order }\end{array}$ \\
\hline$(1)$ & $(2)$ & (3) \\
\hline 1 & Types of production enterprises & global information systems; clusters; technology platforms \\
\hline 2 & World order, socio-economic formation & $\begin{array}{c}\text { States; trade and economic blocks of states; } \\
\text { The process of decentralization of the global unipolar world; } \\
\text { Post-industrial society; }\end{array}$ \\
\hline 3 & $\begin{array}{c}\text { Type of money; } \\
\text { international monetary system }\end{array}$ & $\begin{array}{c}\text { Cryptocurrencies (virtual, technological money); international } \\
\text { cryptocurrency system; global trading systems }\end{array}$ \\
\hline 4 & $\begin{array}{l}\text { Economic policy, Types of } \\
\text { organizational structures in the } \\
\text { economy }\end{array}$ & $\begin{array}{l}\text { Approved innovation policy; clusters, technology platforms; } \\
\text { Organizational architecture; organizational design and culture }\end{array}$ \\
\hline 5 & $\begin{array}{l}\text { The concept of organization } \\
\text { management; the concept of working } \\
\text { with personnel }\end{array}$ & $\begin{array}{l}\text { Theory of technological orders; neuromanagement, } \\
\text { neuromarketing; management of social development of } \\
\text { personnel; higher project education }\end{array}$ \\
\hline 6 & New types of production & $\begin{array}{c}\text { Production of materials with specified properties, } \\
\text { nanotechnology production, environmentally friendly } \\
\text { production; } \\
\text { 3-D printing products, information products, transformation of } \\
\text { human thinking (clip thinking) }\end{array}$ \\
\hline 7 & $\begin{array}{l}\text { Technologies, methods and scales of } \\
\text { production; structure and } \\
\text { characteristics of labor }\end{array}$ & $\begin{array}{c}\text { Nanotechnologies, neurotechnologies, information } \\
\text { technologies; development of mentality and social development } \\
\text { of employees }\end{array}$ \\
\hline
\end{tabular}

Source: Developed by the author

Let's consider these areas of the concept of the organization's transition to a new technological order in more detail.

Recommendations for the further development of the theoretical provisions of the scientific theory of technological orders can cover the development of methodology within each of the functions of this theory. We are talking about such functions of the named theory: methodological function; integrative function; predictive function; preventive function; instrumental function; function of knowledge socialization; and others. The functions of the scientific theory of technological structures are described in more detail in the work [13,pp. 65-82].

The category of events for the development of applied problems of the theory of technological orders by branches of the national economy can include the formation of branch directions of the theory of technological orders. For example, the medical theory of technological orders can study such problems: the correlation between the technological order and the incidence rate of various diseases. In particular, it can be recommended to study the dependence of the level of cardiac diseases on the technological order. Such studies can make it possible to predict the development of various types of diseases within the framework of a new technological order. In addition, within the framework of this direction, the development of medical equipment based on new technologies can be predicted. Projects for the modernization of existing medical equipment can be developed on the basis of technologies of the eighth technological order. In particular, two tables can be developed.

In one table, you can display the change in the structure of the morbidity of the population, depending on the technological order. The second table can reflect the development of medical equipment within certain technological orders.
The sociological direction of the general theory of technological orders can be engaged in forecasting trends in the social development of the population. It is known that there is a connection between the technologies of social production and social relations. For example, such a fact is known. The development of flexible automated production is associated with the sexual revolution of the $1970 \mathrm{~s}$. This is due to the fact that a person has more time and energy for his personal life. The culturological direction of the scientific theory of technological orders can study cultural trends in historical periods corresponding to technological orders and others.

The program for the development of certain technological platforms (neurotechnologies; nanotechnologies; information technologies; resource-saving technologies; digitalization technologies; environmentally friendly technologies) is described in [29, pp. 44-63].

The system of measures aimed at the development of social and industrial institutions of a new technological order is presented in [20, pp. 554-563]. The creation of an integrated management system for the development of a new technological order is reflected in the work [30, pp. 54-63].

Measures to develop a set of indicators to assess the effectiveness of the processes of development and functioning of the new technological order will be reflected in the "Discussion" section of this article.

The process of developing new technologies should be organized. Increased attention should be paid to the process of commercialization of new technologies. Such commercialization should be carried out by purposefully introducing new technologies into existing products. The method of modernization of products or production capacities of enterprises during the transition to a new technological order is as follows. 
(1) It is necessary to study the essence of each of the types of technologies of a new technological order (nanotechnologies, neurotechnologies, and others).

(2) It is necessary to study the design of the modernization object.

(3) Proposals can be formed to improve the safety and comfort of using the modernization object.

(4) Then it is recommended to analyze the possibility of introducing technologies of a new technological order into the design of the modernization object.

(5) It is necessary to evaluate the effect obtained from the introduction of new technologies in the form of increasing the consumer properties of the object of modernization.

(6) It is necessary to assess the economic effect of the work on the modernization of this object.

The economic efficiency of new technologies is determined by the level (depth and number) of integrations (multiplication) of new technologies with technologies of previous technological orders (structures). The concept of "multiplication (multiplication) of technologies" in this paper will be called an integral characteristic of the number and depth of integration of new and old technologies during the transition to a new technological order. The concept of "multiplication of technologies" determines the economic efficiency of the use of new technologies in the national economy of the country. The greater the number of integrations of new technologies with technologies of previous technological orders, the higher the economic efficiency of new technologies.

\section{DISCUSSION}

The subjects of the formation of the concept of the transition of organizations to a new technological order can be: international organizations; national governments; national academies of sciences; political parties; corporate management; developers of new technologies and others.

Acting as a subject in the formation of the concept of the country's transition to a new technological order, political parties can present their ideas on such issues: improving the geopolitical status of the state; rational distribution of productive forces; improving the conditions of socioeconomic development; harmonization of social development; improving medical services for the population and other problems. Political parties may take legislative initiatives. These legislative initiatives can be aimed at developing legal norms that contribute to accelerating the development of a new technological order.

At the same time, political parties are able to provide mentoring to subjects whose activities are aimed at developing a new technological order. Such organizational and social support for developers of new scientific and technological directions is especially important in the initial period of development of a new technological order.

A necessary condition for effective management of the development of a new technological order is the formation of a set of indicators of the effectiveness of this process. Among the indicators of the effectiveness of the concept of the development of a new technological order in the national economy are:

- the percentage in the national economy of innovative products related to the new technological order in the total volume of innovative products;
- an assessment of the percentage of technologies related to the new order in the technological basis of the national economy;

- the amount of revenue per employee in firms of a new technological order;

- the cost of fixed assets of firms belonging to the new technological order;

- the share of firms of a new technological order in the gross domestic product:

- the rate of annual growth of the share of firms of a new technological order in the gross domestic product;

- the percentage of fixed assets of the national economy involved in the production and economic work of organizations related to the new technological order;

- the share of personnel of the national economy working with the use of technologies of the eighth technological department;

- rating of the national economy in the list of states covered by the formation of the new technological order and others.

In the process of developing the concept of the transition of organizations to a new technological order, it is necessary to take into account the situation of a qualitative leap in scientific and technological progress. This jump is due to the formation of a new technological order. At the same time, the fact of the existence of a qualitative leap in scientific and technological progress makes it impossible: the prolongation of trends; the use of statistical methods; the use of analytical models. Heuristic methods gain an advantage.

The next (second) characteristic feature of the synthesis of the concept of transition to a new technological order can be considered that such a concept should be of a systematic technical, economic, organizational nature. At the same time, the very process of forming such a concept can be recognized as a research strategic project. This project of developing such a concept is based on the application of a number of sciences: economics, geopolitics, sociology, technical sciences, the theory of technological order and others. All proposals included in the concept of transition to a new technological order must be scientifically justified. Violation of this provision may lead to errors. Let's consider an example of such an assumed error.

Example \#2. As you know, on November 7, 2010, an article was published in the Financial Times newspaper on the topic of the need to partially return to the gold standard [31]. This proposal was supported by the banking and financial circles. As part of this recommendation of the global monetary authorities, an intensive purchase of gold by central and commercial banks has begun. By July 2011, the price of a troy ounce of gold (weighing 31.4 grams) on the world market was already about $\$ 1920$ per ounce. In this situation, bank analysts believed that by the end of 2011, the price of gold will exceed $\$ 2000$ per troy ounce. At the same time, the crisis in the gold market through the triggering of the "domino effect" could lead to social and political destabilization. Therefore, in July 2011, this situation on the gold market was analyzed in the book [32, pp. 62-63]. In this study, an expert evaluation opinion was expressed that the proposal to partially return to the gold standard can: probably lead to an increased demand for gold; it is possible to stimulate the outflow of money from the real sector of the 
economy; presumably, it does not meet the requirement of the existence of a single methodology for building a monetary system and another. In addition, a detailed analysis of the proposal to return to the gold standard was also carried out in the book [33, p.14]., published at the end of 2011.

The authorities and the banking community were informed about the results of these studies [32 32, p. 62-63; 33, p. 14].

Presumably, statistics show that since the publication of the work [32, p. 62-63] in the middle of July 2011, the price of gold has begun to decline. This contradicted the forecasts of bank analysts published before the publication of this book [32, pp. 62-63].

By the end of 2011, the price of a troy ounce of gold was already about $\$ 1,600$ per ounce. In 2014 , the cost of one ounce of gold was about $\$ 1400$ [34, p. 250-255]. Presumably, the results of scientific research [31-33] could affect the monetary policy and banking practice of purchasing gold. Probably, as a result of such changes, the price of one ounce of gold could decrease by about $\$ 500$ per ounce.

Let us perform an estimated expert assessment of the likely economic effect of such conceptual anti-crisis studies [32, pp. 62-63; 33, p. $14 ; 34$, p. 250-255]. It is known that the weight of bank (thesaurus) gold in the world is about 60,000 tons. Let's divide 60,000 tons of gold by the weight of one troy ounce (31.4 grams). The resulting number of troy ounces $(910,828,025)$ is multiplied by $\$ 500$ (the sum of the price reduction per ounce). Such calculation allows us to assume that the probable economic effect of the described scientific research is [32, p. 62-63; 33, p. 14; 34, p. 250-255] can be about one trillion US dollars? In 2014 , this was the amount: approximately three times more than the budget of Russia; two and a half times more than the initial value of the stabilization fund of the European Union? The above suggested expert opinion may indicate: the high price of possible errors; the need for verification of decisions made by the scientific community; the need for a conceptual approach in the process of forming a new technological order?

The third special methodological feature of the concept of transition to a new technological order should be recognized that such a concept should be formed for the entire life cycle of a new technological order in the global and national economy. Therefore, this concept should be formed before 2040 .

The fourth specific feature of such a concept may be that this concept should include a risk analysis. Based on the results of such an analysis, a list of measures aimed at reducing the risks of transition to a new technological order should be compiled.

The fifth difference between the concept being formed should be recognized that such a conceptshould be based on the results of a predictive analysis. Predictive analysis is aimed at analyzing the future situation that is being formed in the process of transition to a new technological order.

The sixth feature should be considered that such a concept should be reviewed periodically in accordance with changes observed in the external and internal environment of the national economy.

The next (seventh) feature of such a concept should be recognized that such a concept should initially be formed as a flexible document. This concept should initially include the possibility of making changes to goals and tools when the situation changes.

At the same time, it should be borne in mind that the implementation of the approved concept of transition to a new technological order will actually lead to the restructuring of the economy. There will be changes in the life of society.

In this regard, it may be necessary to rebrand the state authorities, corporations and other subjects of the transition to a new technological order. Such rebranding should be accompanied by the development of a private concept of rebranding a specific subject of a new technological order.

Presumably, when forming a general concept of transition to a new technological order, it may happen that a proposal, an event that was not initially approved, after creative modernization may become a significant element of such a concept.

Example \# 3. The proposal to develop a philosophy of rebranding the public administration system was formulated during the preparation of an international scientific conference at the Faculty of Public Administration of Moscow State University. The abstracts of the report entitled "The philosophy of rebranding of domestic public administration" were posted on the Lomonosov portal on 23.03.2019. However, the organizing committee did not approve these theses. At the same time, it is quite possible that these theses, after their supposed creative development, could probably become the starting point of the process of changes in the functioning of the national system of public administration? As you know, such changes were approved in a referendum in 2020.

Further work on the development of the rebranding methodology led to the formation of a general theory of rebranding, reflected in a number of publications [35, pp. 68; 36, pp. 326-345]. This general theory of branding and rebranding of organizations can be a methodology suitable for use by its subjects in the process of developing a new technological order.

\section{CONCLUSION}

The article develops the methodology of a conceptual approach to the development of a new technological order in the economy and society. The concept of transition to a new technological order is understood as a systematic view of this process and the results of the formation of a new technological order.

At the same time, the importance of such a conceptual approach for the successful management of the process of forming a new technological order is justified.

It is shown that the starting point for the formation of such a concept should be a system analysis of a new technological order. The article provides a systematic analysis of the elements and properties of all technological orders.

The article describes the tasks of the branch theory of technological orders in the field of sociology and medicine. The structure of the concept of transition to a new technological order is described and the content of its structural elements is described.

The paper proves that the basis of the methodology for developing such a concept should be: the theory of large systems; the system approach; the theory of technological order. 
It is noted that in the process of developing a new technological order, it may be necessary to rebrand the system of public administration, political parties, corporations and other subjects of the development of a new technological order.

\section{REFERENCE}

[1] Hancharou V. Industrial policy of belarus: conceptual approaches and directions of implementation//Science and Innovations. 2016. № 3 (157). C. 40-43.

[2] Novoselov K. S. Development of the project concept for the organization of production of new products//In the collection: The scientific community of students. Interdisciplinary research. Electronic collection of articles based on the materials of the XXIX student International scientific and practical conference. 2017. pp. 53-55.

[3] Baryshnikov M. S. Conceptual approaches to the formation of an effective system of international innovation cooperation in order to ensure the technological modernization of the economy//Proceedings of the Tula State University. Economic and legal sciences. 2009. No. 2-2. pp. 37-43.

[4] Pavlova A.V. Regional policy as a mechanism for implementing the innovation policy of France//In the collection: Social communications and the evolution of societies. Materials of the $\mathrm{V}$ International Scientific and Practical Conference. Edited by I. A. Waldman; Novosibirsk State Technical University. 2016. pp. 353-358.

[5] Feldman P. Ya. The policy of coordinating interests as a direction of state policy: structural and functional analysis//International relations. 2016. No. 3. pp. 272-278.

[6] Glushchenko I. I. Formation of innovation policy and strategy of the enterprise. - Moscow: APK and PPRO, 2009. - $128 \mathrm{p}$.

[7] Glushchenko V. V. Political science: a systemmanagement approach. - M.: IP Glushchenko V. V., 2008, -160 p.

[8] Aivazov A. (2012). The periodic system of world capitalist development. [Electronic resource] Access mode: http://ajvazov.ru/articles/periodicheskayasistema-mirovogo-kapitalisticheskogo-razvitiya. html, free. Title from the screen. Yaz. rus. (accessed December 2015).

[9] Glazyev S. Yu. World economic structures in global economic development//Economics and mathematical methods. 2016. Vol. 52. No. 2. pp. 3-29

[10] Zagidullina G. M., Sobolev E. A., Krylovsky A. B. Forecasting the structure of the innovative sixth technological order and analyzing the priorities of current industrial development//Proceedings of the Kazan State University of Architecture and Civil Engineering. 2015. No. 1 (31). pp. 182-189.

[11] Orusova O. V., Eliseeva T. S. Development of a strategy for Russia's transition to the sixth technological order//In the collection: The development of modern Russia: problems of reproduction and creation/Collection of scientific papers. Edited by R. M. Nureyev, M. L. Alpidovskaya. 2015. pp. 82-89.
[12] Glushchenko, V. V. (2021). Strategic planning of organizations' transition to the sixth technological order in the national economy// International Journal of Engineering Science Technologies, 5(1), 30-38.

https://doi.org/10.29121/ijoest.v5.i1.2021.159.

[13] Glushchenko, V. V. (2021). The mission and essence of the theory of technological orders// International Journal of Engineering Science Technologies, 5(4), 65-82.

https://doi.org/10.29121/ijoest.v5.i4.2021.205

[14] Glushchenko V. V., The theory of technological orders. - M.: Glushchenko Valery Vladimirovich, 2020. $-80 \mathrm{p}$.

[15] Gluchshenko V. V. Tasks of system analysis of the sixth technological order / / Kazakhstan Science Journal, 2021, vol. 4. No. 3 (28), pp. 22-34.

https://sciencejournal.press/sj/article/view/244/2 01(accessed: 05.03.2021)

[16] Mesarovich M., Mako D., Takahara I. Theory of hierarchical multilevel systems. - Moscow: Mir, 1973. - $344 \mathrm{p}$.

[17] Brzezinski Z. The great chessboard. The dominance of America and its geostrategic imperatives. Moscow: International Relations, 2003. - 250 p.

[18] Glushchenko V. V. Risk management. Insurance. Zheleznodorozhny, M. O., LLP SPC "Wings", 1999. $336 \mathrm{p}$.

[19] Glushchenko V. V. Risks of innovation and investment activity in the conditions of globalization. - Zheleznodorozhny, Moscow region: LLC SPC "Krylia", 2006. - 230 p.

[20] Glushchenko, V. V. (2021). Management System for the Development of Industrial Social Relations of a New Technological Order. International Journal of Scientific Advances (IJSCIA), Volume 2| Issue 4: MayJun 2021, Pages 554-563, URL: https://www.ijscia.com/wpcontent/uploads/2021/07/Volume2-Issue4-JulSep-No.128-554-563.pdf. (accessed 29.07.2021).

[21] Glushchenko V. V. Neurogeopoliticology and methodological aspects of strategic management of geopolitical risk//Modern scientific research and innovation. 2020. No. 4 (108). p. 34. URL: http:/ / web. snauka. ru/issues/2020/04/91886

[22] Glushchenko V. V. Technological theory of postindustrial money / / Finance and Credit, No. 46 (382), 2009, pp. 7-16.

[23] Glushchenko V. V., Glushchenko I. I. The essence of the monetary innovation multiplier in the economy/ / / / Bulletin of Science and practice. 2016. No. 3. pp. 77-88. [Electronic resource].

[24] Glushchenko V. V. Implementation of a strategic project to improve the position of a technical university in the world rankings / / Modern scientific research and innovations. 2021. No. 6 [Electronic resource].

URL:https://web.snauka.ru/issues/2021/06/9584

2 (accessed: 23.06.2021). 
[25] Kolchinsky E. I. N. I. Vavilov And T. D. Lysenko in the space of historical and scientific discussions//Nature. 2018. No. 1 (1229). pp. 3-14.

[26] Glushchenko V. V. General theory of human rights (science of the rights of individuals and legal entities) / / Bulletin of Science and practice. 2018. Vol. 4. No. 8. pp. 303-339.

[27] Glushchenko V. V. Introduction to crisis management. Financial crisis. Anti-crisis management. - Moscow: IP Glushchenko V. V., 2008, - 88 p. ISBN 978-5-99014062-2;

[28] Nanotechnologies as a key factor of a new technological structure in the economy / Edited by S. Yu. Glazyev and V. V. Kharitonov. - Moscow: Trovant, $2009-304 p$

[29] Glushchenko V. V. Tools for the development of a neurotechnological platform in mechanical engineering of the sixth technological order/ / Kazakhstan Science Journal, 2020, No. 1 (14), pp. 44 63.https://sciencejournal.press/sj/article/view/13 $8 / 123$

[30] Glushchenko V. V. The paradigm of intellectual management of the formation of the sixth technological order in the economy// The scientific heritage, 2020, vol. 4, No. 45 (2020), p. 54-63.

[31] Parmy Olson. Zoellick Suggests Return to Gold Standard//FORBES; Nov 8, 2010,
[32] Glushchenko V. V. Corruptiology: social aspect (social corruptiology) - Moscow: IP Glushchenko Valery Vladimirovich, 2012. - 88 p.; ISBN 978-5904542-11-5.

[33] Glushchenko V. V. The science of money: the technological theory of money. - Moscow: IP Glushchenko Valery Vladimirovich, 2012. - 88 p., ISBN 978-5-904542-12-2

[34] Glushchenko V. V. Krisologiya-2014: methodological aspects of global anti-crisis management// Russia: trends and prospects of development, Yearbook, Issue 10, Part I; INION RAS, 2014, pp. 250-255

[35] Glushchenko V. V., Goncharov I. A., Omelchenko V. D. Policy of rebranding of economic entities//Scientific achievements: theory, methodology, practice. Collection of scientific papers based on the materials of the VI International Scientific and Practical Conference. - Anapa (28.03.2019), Innova Research Center, pp. 6-8.

[36] Glushchenko V. V. The scientific theory of brands branding and rebranding (brandology) and the tasks of its practical use in organizations / / Bulletin of Science and practice. 2020. Vol. 6. No. 5. pp. 326-345. https://doi.org/10.33619/2414-2948/54/43 